\title{
Steroid hormone receptors in human salivary gland
}

\section{tumours}

\author{
P-J LAMEY,* R E LEAKE, $\dagger$ S K COWAN, $\dagger$ D S SOUTAR, $\ddagger$ I A MCGREGOR $\ddagger$ \\ F M MCGREGOR§
}

From the *Department of Oral Medicine and Pathology, Glasgow Dental Hospital and School, $\dagger$ Department of Biochemistry, University of Glasgow, $\ddagger$ Plastic Surgery Unit, Canniesburn Hospital, Bearsden, §Department of Pathology, Royal Infirmary, Glasgow, Scotland

SUMMARY Major salivary gland tumours were studied for the presence of hormone receptors for oestrogen and progesterone. Of the eight salivary gland tumours exhibiting varied histology, none showed high affinity receptors for oestrogen or progesterone. Salivary tissue from four patients with non-neoplastic salivary gland disease was also studied and found not to contain high affinity receptor sites. The absence of hormone receptors in these glands suggests that such tumours are not dependent on endocrine function.

Studies of human breast tumours ${ }^{1}$ and human colon cancers $^{2}$ have shown the presence of steroid hormone receptors to oestrogen and progesterone in some cases. High affinity binding sites to other steroid hormones, such as dihydrotestosterone and glucocortoid, may also be found in these tumours. Evidence is accumulating concerning other hormone dependent malignancies, including some types of acute leukaemia,${ }^{3}$ cancer of the prostate, ${ }^{4}$ endometrial cancer ${ }^{5}$ and other solid tumours ${ }^{6}$. The sequence of events whereby steroid hormones interact with receptor proteins and induce protein production is not fully understood, but it is generally accepted that the presence of steroid receptors is crucial to the hormone responsiveness ${ }^{7}$ of target tissue.

The association of breast cancer and salivary gland tumours is well known in $\operatorname{man}^{8}$ and animals. ${ }^{9}$ Common aetiological factors for these two tumours have also been proposed.

This preliminary study shows that human salivary gland tumours do not contain steroid hormone receptor sites often associated with hormone dependent tumours.

\section{Material and methods}

Six men and six women with suspected neoplastic and non-neoplastic salivary gland release were selected for study. The age range of the patients was $29-80$ years (mean $45 \cdot 7$ years). No patient was taking oestrogens

Accepted for publication 3 December 1986 before surgery, and only one patient was postmenopausal.

At operation the affected salivary gland was removed and sampling of the tumour or non-tumour tissue undertaken. Care was taken to sample the salivary tissue for hormone analysis adjacent to the area to be subjected to routine histopathological examination. Of the patients with non-neoplastic salivary disease (three male and one female), three patients had chronic sialadenitis and one patient had normal parotid tissue. Table 1 gives the details of these patients and the histological diagnoses

Samples of tissue for steroid receptor assay were transported on ice to the laboratory and either assayed fresh or stored as previously described. ${ }^{10}$ Tissue was homogenised and separated into soluble and nuclear fractions by our standard procedure. ${ }^{7}$ Oestrogen receptor values were determined in both fractions by a 7-point saturation assay using tritiated oestradiol (range $0 \cdot 2-3 \mathrm{nmol} / \mathrm{l}$ ) either with or without a 200-fold excess of diethylstilboestrol to eliminate non-specific binding. Results were analysed by Scatchard analysis. Progesterone receptor values were determined in a similar assay which used tritiated ORG-2058 (Organon Synthetic Progestin) (range $0 \cdot 5-5 \mathrm{nmol} / \mathrm{l})$ with or without unlabelled ORG-2058 at 200-fold excess concentration. All buffers contained $15 \%$ glycerol for the progesterone receptor assay.

Receptor values were only considered to be positive when the "best-fit" line could be constructed using at least five of the points plotted after correction for 
Table 1 Summary of clinical features of patients studied and histological diagnosis of their salivary gland lesions

\begin{tabular}{lllll}
\hline Case No & Sex & Age & Site of tumour & Tumour histology \\
\hline 1 & F & 80 & Left parotid & Pleomorphic salivary adenoma \\
2 & M & 34 & Right parotid & Chronic sialadenitis \\
3 & F & 38 & Left parotid & Pleomorphic salivary adenoma \\
4 & F & 45 & Reft parotid & Adenocarcinoma \\
5 & M & 41 & Left parotid & Pleomorphic salivary adenoma \\
6 & M & 44 & Right parotid & Pleomorphic salivary adenoma \\
7 & F & 42 & Carcinoma ex-pleomorphic salivary \\
8 & F & 48 & Left parotid & adenoma \\
9 & M & 64 & Right submandibular & Normal tissue \\
10 & M & 64 & Chronic sialadenitis \\
11 & F & 20 & & Chronic sialadenitis \\
12 & M & 29 & &
\end{tabular}

non-specific binding. This approach to receptor assays helps to eliminate binding due to proteins other than the specific high affinity, saturable cellular receptors. ${ }^{11}$ All assays are subject to strict quality control. $^{12}$

\section{Results}

Scatchard analysis of high affinity receptor binding protein was undertaken on all specimens. Table 2 shows the results. None of the assays was positive for high affinity receptor sites from oestrogen and none of the patient's salivary tissue samples was progesterone receptor positive.

\section{Discussion}

Sexual dimorphism of murine salivary glands has been well documented. ${ }^{13}$ The submandibular glands of mice are particularly affected, and the histological changes seen generally entail granular tubule cells. ${ }^{14}$ This dimorphism is thought to be mediated by steroid sex hormones which are also known to have a role in the granular tubule cell content of growth factors- namely, epidermal growth factor. ${ }^{15}$ These physiological differences between male and female murine salivary glands are probably established at or before puberty, and sex steroid responses mediated through the high affinity receptor probably do not occur in most salivary gland cells in mature adults. A small select group of cells may retain sex steroid receptors, but this would only be detectable using an immunocytochemical assay. ${ }^{16}$

An association between breast tumours and salivary tumours in man has been reported. ${ }^{18}$ In addition, experimental manipulation of sex hormones in mice induces secondary primary tumours of breast ${ }^{9}$ in animals which would normally only develop salivary gland tumours selectively. ${ }^{17}$ It is postulated that as the salivary tumours were well differentiated (pleomorphic salivary adenomas) they may produce epidermal growth factor and that this may be important in the subsequent breast tumour growth occurring in vitro. ${ }^{18}$ In practice raised values of epidermal growth factor receptors in breast tumours are associated with loss of oestrogen receptors. ${ }^{19}$

To our knowledge hormonal treatment has not been suggested or tried in patients with salivary gland

Table 2 Analysis of oestrogen and progesterone receptors in human salivary samples

\begin{tabular}{|c|c|c|c|c|}
\hline Case No & Cytosol protein $(\mathrm{mg} / \mathrm{ml})$ & Nuclear DNA (mg/ml) & Oestrogen receptor assay & Progesterone receptor results \\
\hline $\begin{array}{l}\text { Tumour } \\
1 \\
3 \\
4 \\
5 \\
6 \\
7 \\
8 \\
9\end{array}$ & $\begin{array}{l}2 \cdot 1 \\
2.75 \\
4.05 \\
1.7 \\
1.65 \\
0.43 \\
4.05 \\
1.4\end{array}$ & $\begin{array}{r}51 \\
185 \\
250 \\
120 \\
170 \\
33 \\
190 \\
168\end{array}$ & $\begin{array}{l}\text { ND } \\
\text { ND } \\
\text { ND } \\
\text { ND } \\
\text { ND } \\
\text { ND } \\
\text { ND } \\
\text { ND }\end{array}$ & $\begin{array}{l}\text { ND } \\
\text { ND } \\
\text { ND } \\
\text { ND } \\
\text { ND } \\
\text { ND } \\
\text { ND } \\
\text { ND }\end{array}$ \\
\hline $\begin{array}{l}\text { Without tumour } \\
2 \\
10 \\
11 \\
12\end{array}$ & $\begin{array}{l}1 \cdot 0 \\
1 \cdot 15 \\
2 \cdot 95 \\
2 \cdot 4\end{array}$ & $\begin{array}{r}39 \\
120 \\
120 \\
250\end{array}$ & $\begin{array}{l}\text { ND } \\
\text { ND } \\
\text { ND } \\
\text { ND }\end{array}$ & $\begin{array}{l}\text { ND } \\
\text { ND } \\
\text { ND } \\
\text { ND }\end{array}$ \\
\hline
\end{tabular}

${ }^{*} \mathrm{ND}=$ not detectable; assay detects receptor in excess of $0.1 \mathrm{fmol} / \mu \mathrm{g}$ DNA. 
tumours. The results of our study suggest that hormonal manipulation is unlikely to be effective, as salivary gland tumours do not contain high affinity oestrogen receptors.

We thank Dr DG MacDonald and Dr JS Rennie for providing the histological diagnoses.

\section{References}

1 McGuire WL, Carbone PP, Vollmer EP. Oestrogen receptors in human breast cancer. New York: Raven Press, 1975.

2 Afford TC, Hoan-My D, Geelhoed GW, Tsangaris NT, Lippman ME. Steroid hormone receptors in human colon cancers. Cancer 1979;43:980-4.

3 Lippman ME, Halterman RH, Leventhal BG, Perry S, Thompson EB. Glucocorticoid binding proteins in human acute lymphoblastic leukaemia blast cells. J Clin Invest 1973;52:1715-9.

4 Hsu RS. Androgen receptors in human prostates. In: Normal and abnormal growth of the prostate. Springfield, Illinois: Charles C Thomas, 1975:663-75.

5 Pollow K, Lubbert H, Boquoi E, Kreuzer G, Pollow B. Characterisation and comparison of receptors for 17- $\beta$ estradiol and progesterone in human proliferative endometrium and endometrial carcinoma. Endocrinology 1975;96:319-24.

6 Leake RE, Laing L, Calman KC, Macbeth FR. Steroid receptor status and response to endocrine treatment in patients with non-endocrine solid tumours. Cancer Treatment Rep 1980;64:797-801.

7 Leake RE, Laing L, Calman KC, Macbeth FR, Crawford D, Smith DC. Oestrogen receptor status and endocrine therapy of breast cancer: response rates and status stability. $\mathrm{Br} J$ Cancer 1981;43:59-66.

8 Prior $\mathrm{P}$, Waterhouse JAH. Secondary primary cancers in patients with tumours of the salivary glands. Cancer 1977;36:362-6.

9 Lamey P-J, Ferguson MM, Marshall W. Sex hormone involvement in the development of experimental virally induced murine salivary gland tumours. J Oral Pathol
1985;14:414-21.

10 Crawford D, Cowan S, Hyder S, McMenamin M, Smith D, Leake RE. A new storage procedure for tumour biopsies prior to oestrogen receptor measurement. Cancer Res 1984;46: 2348-56.

11 Leake RE. Steroid receptors. In: Birnie GD, MacGillivray AJ. Nuclear structures: their isolation and characterisation. London: Butterworths, 1985.

12 Koenders A, Thorpe SM. Standardisation of steroid receptor assays in human breast cancer 1. Reproducibility of estradiol and progesterone receptor assays. Eur J Cancer Clin Oncol 1983;19:1221-9.

13 Junqueira LC, Fajer A, Rabinovitch M, Frankenthal L. Biochemical and histochemical observations on sexual dimorphism in mice. Journal of Cellular and Comparative Physiology 1949;34:129-39.

14 Hosoi K, Nankamura T, Ueha T. Effects of testosterone on the amount of serous-like granules in convoluted tubule cells of mouse submandibular glands. J Biochem 1977;81:739-43.

15 Hosoi K, Aoyama K, Ueha T. Regulation of the secretory process of granular components of the convoluted tubular cells of the mouse submandibular gland. J Dent Res 1978;57:87-95.

16 Crawford DJ, Lope Pyhie A, Cowan S, George WD, Leake RE. Pre-operative determination of oestrogen receptor status in breast cancer by immunocytochemical staining of fine needle aspiration. Br J Surg 1985;72:991-3.

17 Lamey P-J, Waterhouse JP, Ferguson MM. Animal model of human disease: pleomorphic salivary adenoma. Am J Pathol 1982;109:129-32.

18 Turkington FW. Stimulation of mammary cancer cell proliferation by epithelial growth factor in vitro. Cancer Res 1964;29:1457-9.

19 Sainsbury JRC, Farndon JR, Harris AL, Sherbert GV. Epidermal growth factor receptors on human breast cancers. $\mathrm{Br} J$ Surg 1985;72:186-9.

Requests for reprints to: Dr P-J Lamey, Department of Oral Medicine and Pathology, Glasgow Dental Hospital and School, 378 Sauchiehall Street, Glasgow G2 3JZ, Scotland. 